\title{
ポリブチレンテレフタレート／ポリ乳酸系アロイ材料の 成形性および特性
}

川口邦 明*

\section{1. 緒言}

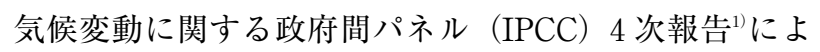
ると, 二酸化炭素 $\left(\mathrm{CO}_{2}\right)$ を中心とする温室効果ガスの増 加による地球温暖化の進行と, それに伴う気候・環境の変 化が憂虑されている．また，地球資源の面では，原油の新 規発見埋蔵量の減少や，原油使用量の増加に伴う化石資源 の枯渴が危惧されている.いずれも, 我々人類が直面して いる長期リスクと言える．年々，環境・資源問題がクロー ズアップされ，その対応策が社会的に求められる中で, 数 千万〜数億年をかけて地中に埋蔵された化石資源が短い期 間で消費され， $\mathrm{CO}_{2}$ として大気に放出されるというサイク ルそのものに警鐘が鳴らされている.

これに対して, $\mathrm{CO}_{2}$ から植物の光合成により生成したバ イオマスは, Renewable（再生可能）資源と表現され, 燃 料・化成品への変換により化石資源の使用量を削減するこ とができるとともに, $\mathrm{CO}_{2}$ 増加を抑制できることから，そ の有効利用が近年注目されている.ポリ乳酸（PLA）は, 上記のような背景の中で, バイオマス由来の材料として広 く認知され, 検討が活発化しており, また, 化石資源をべー スとしたプラスチックにPLA を配合し，複合化する検討 も広く行われている2). しかし, PLA は材料性能として, 成形性, 耐熱性, 耐衝撃性, 耐加水分解性などに劣るため, 複合化した樹脂組成物の成形性や特性に対して, PLA 自 体が阻害要因となることが多く, また相手樹脂に与える長 所が少ないため，更なる改善が望まれていた.

一方，ポリブチレンテレフタレート（PBT）は，優れ た機械的特性, 電気的特性, 耐熱性等を有するエンジニア リングプラスチックであり, 自動車部品, 電気・電子部品 などの種々の用途に広く利用されている. PBT は, GF（ガ ラスファイバー）等の無機フイラーの充填により, 機械的 特性や耐熱性が格段に向上することが知られており，無機 フィラー充填 PBT は, ポリマーアロイのベース材料とし

\footnotetext{
* Kawaguchi, Kuniaki

ポリプラスチックス秼）研究開発センター

富士市宮島 973 ( ₹ 416-8533)

kuniaki.kawaguchi@polyplastics.com

2012.2.1 受理
}

ても大きなポテンシャルを有しているものと考えられる. 今回我々はこれに着目し，GF 充填 PBT をべースに新た にPBT/PLA 系のアロイ材料を開発した ${ }^{3)}$. 本報では，そ の成形性㧍よび特性について述べるとともに, 成形性の評 価技術，また，PLAを用いることにより得られる新たな 特性についても言及する。

\section{2. 実験}

\section{1 試料}

PBT/PLA 系のアロイ材料（開発材料）を, PBT（ウィ ンテックポリマー(侏製)，PLA (25 wt\%)，GF (30 wt\%), 改質剂・改良剂を用いて二軸押出機により調製した。また， $\mathrm{PBT}$ (同製)，GF (30 wt\%) を含有する一般的な $\mathrm{PBT}$ 系 材料を, 同機により調製した。 また, 成形性, 耐加水分解 性評価等のための比較材料として, PBT (同製), PLA (25 $\mathrm{wt} \%), \mathrm{GF}(30 \mathrm{wt} \%)$ を含有する PBT/PLA 系材料（従 来材 $1 ， 2 ） を ，$ 同機により調製した.

\section{2 相構造観察}

走查型電子顕微鏡（SEM，日立製作所製 S-4700）を用 いて，曲げ試験片（コア部流動垂直方向）のミクロトーム 切削面を観察した。

\section{3 成形性評価 4 , 5)}

$\mathrm{a}$. 離型可能な冷却時間の評価

射出成形機を用いて, 図 1 に示す形状の成形品を, 保圧 20 100 MPa の範囲で変化させ成形し, 離型可能な最小 冷却時間を測定した。使用した成形品は長面側の中央にリ ブ部が，また，その片側にボス状の細い円柱が設置され， さらに，イジェクトピンが別の片側の中央から突き出すよ うに設定されており, リブ部と細い円柱の存在のため, 離 型し難い形状で構成されている.な拀, 成形は, シリンダー 温度 $250^{\circ} \mathrm{C}$, 金型温度 $60^{\circ} \mathrm{C}$, 射出速度 $20 \mathrm{~mm} / \mathrm{s}$ で行なった。 $\mathrm{b}$. 離型抵抗值の直接測定

射出成形機を用いて, 円筒形状の成形品と格子形状の成 形品を成形し, その際の成形品突き出し時の離型抵抗值を, イジェクトピンの裏側に設置した圧力センサーにて所定の 保圧ごとに直接測定した（図 2). 離型抵抗值は, 成形品 の突き出し時の最大值で表し, 成形品が無い状態での突き 出し時の抵抗値を差し引いて算出した. 図 2 では円筒形状 
の成形品を使用した場合の金型断面の概要図を示している. なお，成形は，シリンダー温度 $250^{\circ} \mathrm{C}$, 金型温度 $60^{\circ} \mathrm{C}$, 射 出速度 $20 \mathrm{~mm} / \mathrm{s}$ ，冷却時間 $10 \mathrm{~s}$ で行なった.

\section{4 特性評価}

a. 機械的特性評価

ISO $527-1 ， 2$, ISO 178 , ISO $179 / 1$ eA, ISO $75^{-1}$ ， 2 に準拠し, 引張特性, 曲げ特性, シャルピー衝撃強さ(ノッ

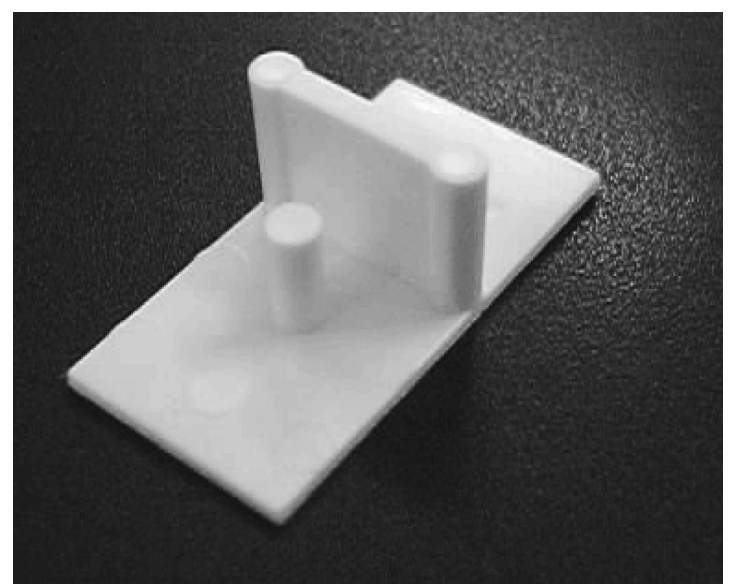

図 1 冷却時間の評価に用いた成形品
チ付)，荷重たわみ温度（DTUL，荷重：1.8 MPa）をそ れぞれ評価した。

b. 寸法精度 (そり変形性) 評価

$80 \mathrm{~mm}$ 角の平板状試験片を，試験片厚さおよび射出成 形時の保圧を変えてそれぞれ成形し，成形品のそり変形性 を評価した。

\section{c．耐トラッキング性評価}

International Electrotechnical Commission (IEC) 112 第 3 版に準拠し, 滴下溶液として $0.1 \%$ 塩化アンモニウム 水溶液を，印加電極として白金電極を用いて，3 $\mathrm{mm}$ 厚の 平板状試験片にトラッキングが生じる印加電圧を測定した. d. 耐加水分解性評価

成形した引張試験片を，恒温恒湿器内で $60^{\circ} \mathrm{C} \cdot 85 \% \mathrm{RH}$ の条件下で曝露処理し, その後, 引張試験を行い, 未処理 の引張特性值に対する保持率を求めた.

\section{3 ．結果と考察}

\section{$3.1 \mathrm{PBT} / \mathrm{PLA}$ 系アロイ材料の相構造}

モルフォロジー調査の観点から，曲げ試験片（コア部流 動垂直方向）のミクロトーム切削面の SEM 観察を実施し た. 結果を図 3 に示す。改良前のPBT/PLA 系材料（従 来材 1) を観察した図 3 (a)では，写真左上部に GF 断面の

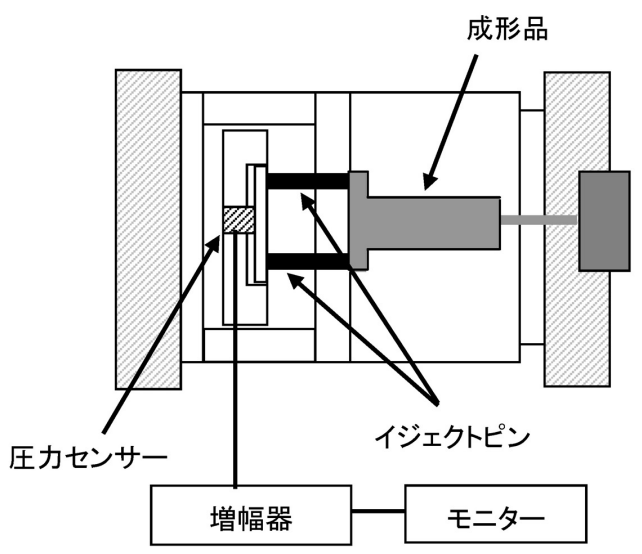

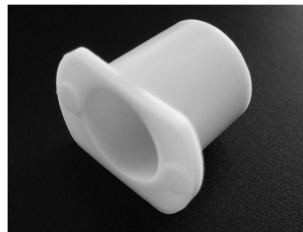

円筒形状の成形品

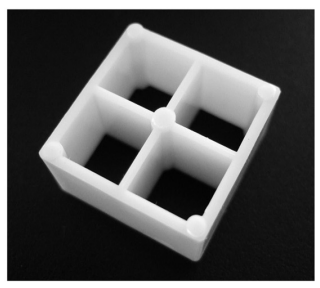

格子形状の成形品

図 2 離型抵抗値の直接測定の概要図および使用した成形品

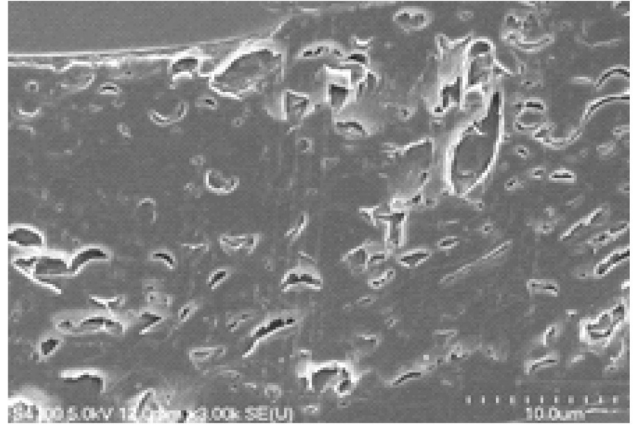

(a)

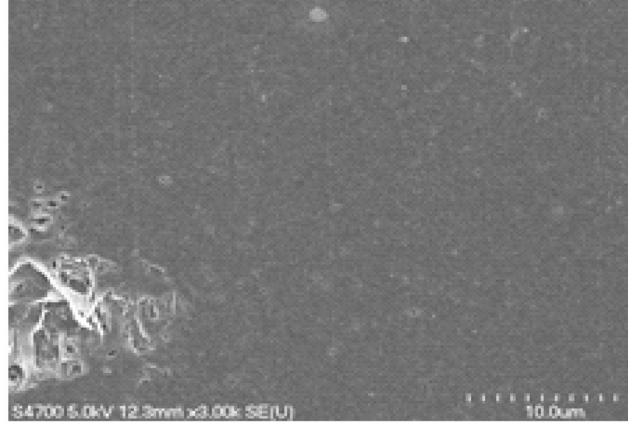

(b)

図 3 曲げ試験片（コア部流動垂直方向）のミクロトーム切削面の SEM 観察写真：(a) 改良前の PBT/PLA 系材料（従 来材 1),（b） PBT/PLA 系の開発材料 
一部があり, それ以外の PBT マトリックス中では PLA ドメインの剥離が観察され，ドメインサイズにばらつきが 見られるとともに，変形した $5 \mu \mathrm{m}$ レベルの大きなドメイ ンも観察される。一方, PBT/PLA 系の開発材料では, PBT マトリックス中での PLA ドメインの剥離は減り, ドメイ ンサイズも小径化し，均一化している（図 3(b)). なお, 図 3(b) 写真左下部は切削面の乱れが見られるが，これは $\mathrm{GF}$ 近傍による切削位置の影響によるものである. SEM 観察された開発材料における PLAの良分散・良親和性の 傾向は, 改質剤・改良剤を用いたアロイ化技術による PBT /PLA 界面構造の制御と, 界面密着性の改善により発現し たものと考えられる。

\section{$3.2 \mathrm{PBT} / \mathrm{PLA}$ 系アロイ材料の成形性}

$\mathrm{a}$. 離型可能な冷却時間の評価

各材料について, 図 1 に示す形状の成形品を用いて離型 可能な最小冷却時間の評価を行なった。結果を図 4 に示す. 本評価法では, 冷却時間が短い場合には離型時の成形品の 収縮が小さく, また, さらに固化が不十分な材料の場合に は弾性率が低くなるため, 変形を生じ, 離型不良が発生し やすくなる。 また, 保圧力が高い場合には, 充填量が増加 し離型時の成形品リブ部の収縮が小さくなるため, 同じく 離型不良が発生しやすくなる。 なお，本評価で離型不良と は, 突き出し時に成形品リブ部の付け根が破壊または大き く変形するケースの他, 金型に密着し取出し不能となる ケースも含む.

材料間で比較すると, PBT/PLA 系の開発材料は, 改良 前の PBT/PLA 系材料（従来材 1, 2）に比べて, 離型可 能な冷却時間が大幅に短縮しており, 一般的な PBT 系材 料と同等の成形サイクルを有していることがわかる. 参考 として, PLA 樹脂単体を本方法にて評価したが，保圧条 件範囲において, いずれも離型不良のため, 冷却時間は計 測不可であった.

ここで，本成形品を両持ち梁として単純化して考えると， 離型抵抗と成形品物性との関係は以下の式 1,2 で表現さ れ，金型断面から見た構成は図 5 で示される ${ }^{4)}$.

\section{$\mathrm{h}=\mathrm{P}^{\prime} \mathrm{L}^{3} / 4 \mathrm{bd}^{3} \mathrm{E}$

$$
\mathrm{P}=\mathrm{k} \mu \mathrm{E}\left(\varepsilon_{0}-\varepsilon\right)
$$

(h : 変形量, $\mathrm{P}^{\prime}$ : 成形品突き出し力, $\mathrm{L}$ ：スパン, b : 幅,

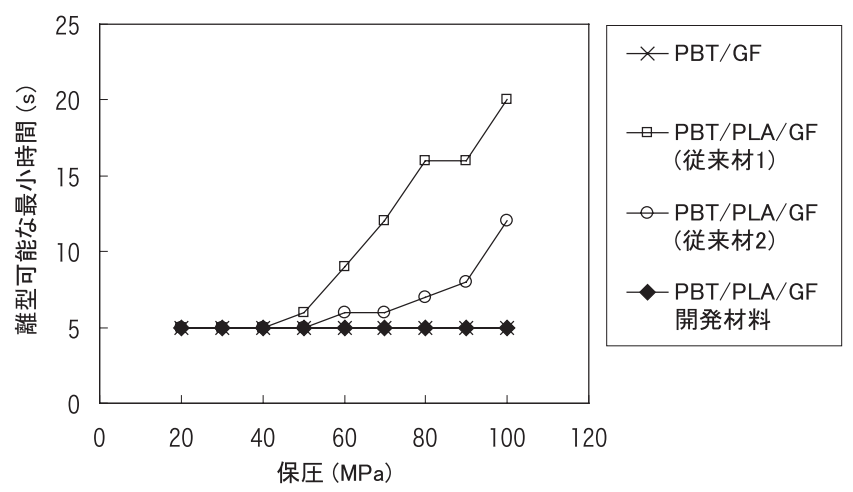

図 4 関係 $\mathrm{d}$ : 厚み, $\mathrm{P}$ : 離型抵抗力, $\mu$ : 離型時の金型と成形品との 摩擦係数, $\mathrm{E}$ : 離型時の弾性率, $\varepsilon_{0}$ : 初期歪, $\varepsilon$ : 離型時の 収縮率, $\mathrm{k}$ : 係数)

すなわち, 成形品突き出し力 $\mathrm{P}^{\prime}$ が大きく, 離型抵抗力 $\mathrm{P}$ が小さくなるほど離型性に有利となるため, (a) 変形量 h を大きくても破損しない材料強度を有し，（b) 摩擦係数 $\mu$ が低く, (c) 収縮率 $\varepsilon$ の高い材料が離型性能に優れること になる. 本開発材料では, 収縮率については一般的な PBT 系材料に比べて高くないことが別の評価で確認されている ため，影響因子としては，特に，(a)，（b）が関与してい るものと考えられる.

\section{b . 離型抵抗值の直接測定}

次に，円筒形状および格子形状の成形品の離型抵抗值を， イジェクトピンの裏側に設置した圧力センサーにて所定の

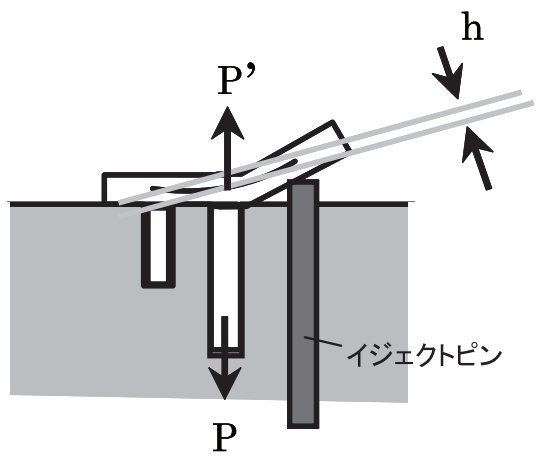

図 5 成形品の金型断面から見た構成

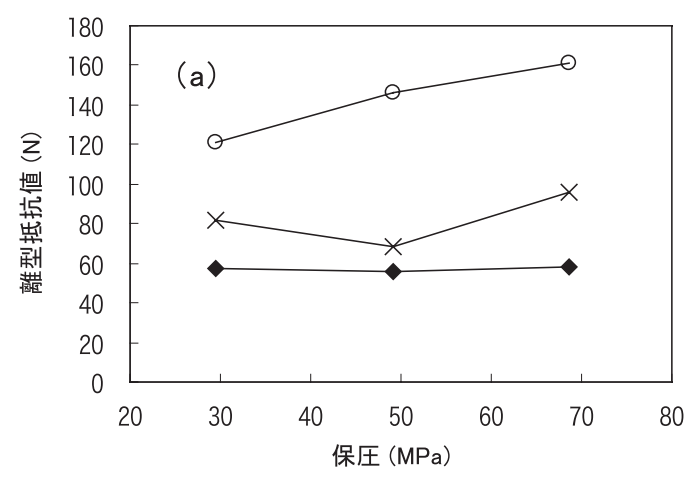

\begin{tabular}{|c|c|c|}
\hline$\star \mathrm{PBT} / \mathrm{GF}$ & $\begin{array}{c}-\mathrm{PBT} / \mathrm{PLA} / \mathrm{GF} \\
(\text { (従来材 } 2)\end{array}$ & $\begin{array}{c}\longrightarrow P B T / P L A / G F \\
\text { 開発材料 }\end{array}$ \\
\hline
\end{tabular}

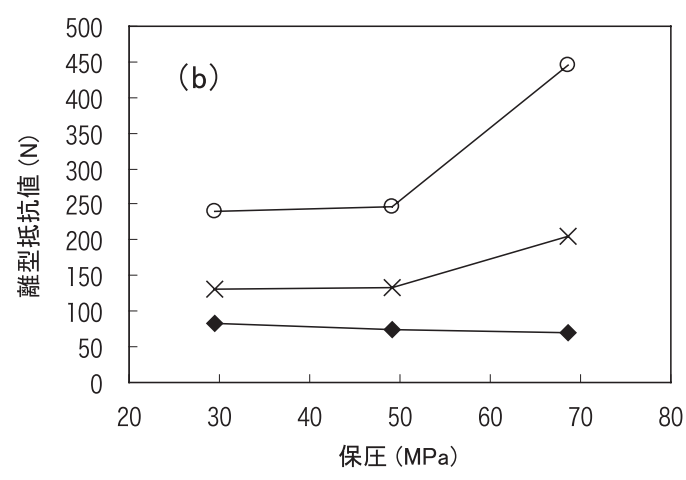

$\times$ PBT/GF $\multimap$ PBT/PLA/GF $\longrightarrow$ PBT/PLA/GF (従来材2) 開発材料

図 6 各材料における離型抵抗值と保圧との関係：(a) 円 筒形状の成形品,（b）格子形状の成形品 
保圧ごとに直接測定した。評価結果を図 6 に示す。本試験 方法では，一般に円筒形状の成形品（図 6(a)) よりも格 子形状の成形品（図 6(b)）の方が, 高保圧側で離型抵抗 值の増加が顕著となる傾向にある。これは，円筒形状の成 形品では収縮変形によるコア金型部（円筒内部）への抱き 付きが保圧の上昇により抑えられるのに対して, 格子形状 の成形品では充填量増加により収縮が小さくなり, コア金 型部（4つの四角形状）への抱き付き力が上昇し, 金型へ の抵抗值が増加するためである.

材料間で比較した場合，円筒形状および格子形状の成形 品ともに, PBT/PLA 系の開発材料の離型抵抗值は, 改良 前の PBT/PLA 系材料（従来材 2）に比べて低減し，一般 的な PBT 系材料と同等レベルの離型性能を有しているこ とがわかる。また，開発材料は，保圧条件範囲いずれにお いても，離型抵抗值の保圧依存性が低い傾向を示している。 これらの結果は, 前項の離型可能な冷却時間の評価結果と

ともに, 本開発材料の優れた離型性能を示している.

\section{$3.3 \mathrm{PBT} / \mathrm{PLA}$ 系アロイ材料の特性}

a. 環境特性

PBT/PLA 系の開発材料の樹脂生産から焼却に至るサイ クルに扔ける $\mathrm{CO}_{2}$ 発生量を，一般的な $\mathrm{PBT}$ 系材料との比 率で試算した結果を表 1 に示す。なお， $\mathrm{CO}_{2}$ 発生量の試算 は産業環境管理協会のデー夕等を基に行なった。試算の結 果, 開発材料の $\mathrm{CO}_{2}$ 発生量は, 比較材料に対して約 2 割 低減することが示唆された.

\section{b. 機械的特性}

PBT/PLA 系の開発材料の機械的特性の評価結果を表 1 に示す. 比較の一般的な PBT 系材料に対して, 強度, 勒 性（引張破壊ひずみ，シャルピー衝撃強さ）の低下が少な い傾向にあり, PLA 添加による物性低下は比較的抑えら れている.これは, 図 3(b)で示した良分散・良親和性の 相構造の傾向が影響しているためと考えられる。また，曲 げ弾性率は，比較の PBT 系材料を上回る傾向を示してお り, PLA の有する高弾性率の傾向 ${ }^{6}$ が反映したものと推定 される.荷重たわみ温度については，比較の PBT 系材料 に対して低下するものの，PLA を用いた従来アロイ材料 の荷重たわみ温度の例 $\left(\mathrm{PC} / \mathrm{PLA}: 78 \sim 95^{\circ} \mathrm{C}(1.8 \mathrm{MPa})^{7)}\right.$, ABS $/ \mathrm{PLA}: 78 \sim 92^{\circ} \mathrm{C}(0.46 \mathrm{MPa})^{8)}, \mathrm{PP} / \mathrm{PLA}: 66 \sim$ $92^{\circ} \mathrm{C}^{9)}$ ) に比べて高い值を有しており，耐熱性の高い $\mathrm{GF}$ 充填 PBT がベースマトリックスとなっている効果が発現 している。

\section{c．寸法精度（そり変形性）}

平板状試験片の各保圧・厚さにおけるそり量の評価結果 を図 7 に示す。いずれも一定のそり量が計測される。この ような結晶性樹脂材料の薄肉成形品に見られるそりは，樹 脂結晶化による収縮の異方性が原因とされ，GFのような フィラーを充填した材料では頻繁に観察されている。保圧 が高い場合は，樹脂量が増加するとともに，また，固化の 過程で圧力による矯正が行なわれるため，一般にそり量は 低減する傾向にある。また，成形品の厚さが増加するほど， 成形品自体の剛性が高まるため，同じくそり量は低減する。

PBT/PLA 系の開発材料は一般的な PBT 系材料に比べ てそりが抑えられ，特に $2 \mathrm{~mm}$ 厚の試験片では比較材料に 対して $1 / 5$ 以下の低そり性を有している。この結果は, 含
表 $1 \mathrm{PBT} / \mathrm{PLA}$ 系の開発材料と PBT 系材料の特性

\begin{tabular}{|c|c|c|c|c|}
\hline 特性項目 & 詳細項目 & 単位 & $\begin{array}{l}\mathrm{PBT} / \mathrm{PLA} / \mathrm{GF} \\
\text { 開発材料 }\end{array}$ & $\mathrm{PBT} / \mathrm{GF}$ \\
\hline \multirow{2}{*}{ 環境特性 } & バイオ成分 & $\%$ & 25 & 0 \\
\hline & $\mathrm{CO}_{2}$ 発生量 (対 PBT/GF) & $\%$ & 78 & 100 \\
\hline 物理特性 & 比重 & - & 1.51 & 1.53 \\
\hline \multirow{5}{*}{ 機械特性 } & 引張強さ & $\mathrm{MPa}$ & 145 & 140 \\
\hline & 引張破壊ひずみ & $\%$ & 2.0 & 2.2 \\
\hline & 曲げ強さ & $\mathrm{MPa}$ & 190 & 220 \\
\hline & 曲げ弾性率 & $\mathrm{MPa}$ & 9300 & 9030 \\
\hline & シャルピー衝撃強さ & $\mathrm{kJ} / \mathrm{m}^{2}$ & 8 & 11 \\
\hline 熱特性 & 荷重たわみ温度 (1.8 MPa) & ${ }^{\circ} \mathrm{C}$ & 180 & 213 \\
\hline 電気特性 & 耐トラッキング性 & $\mathrm{V}$ & $>600$ & 350 \\
\hline
\end{tabular}

$\mathrm{CO}_{2}$ 発生量：产業環境管理協会デー夕等を基に試算

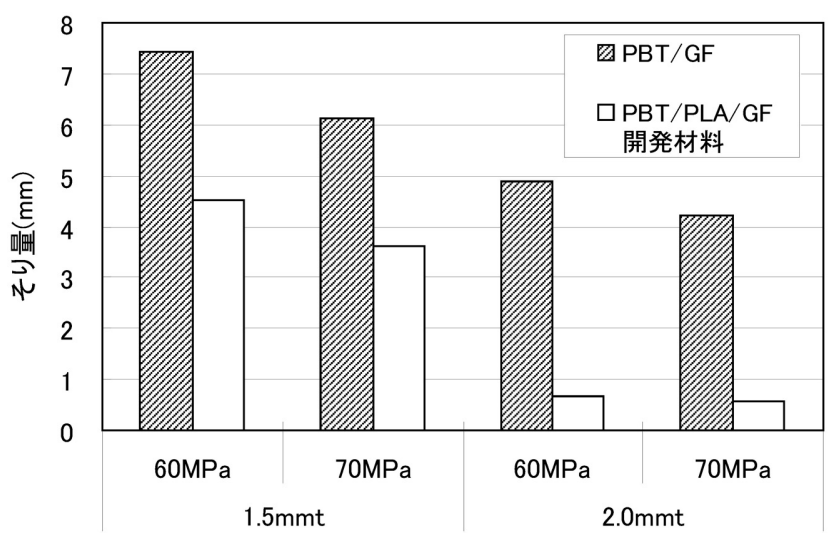

図 $780 \mathrm{~mm}$ 角の平板状成形品の各保圧・厚さにおけるそ り量

有している PLA が, 結晶化速度の速い PBT マトリック スの収縮変形に対して, 緩和的な働きをしているためと推 定される. 本特性は, PLA を用いることで発現される新 たなメリットであり，そり低減による薄肉設計への応用に 繋がるものと考えられる。

$\mathrm{d}$ ．耐トラッキング性

平板状試験片を用いた耐トラッキング性試験の結果を表 1 に，また，試験後の試験片の状態を図 8 に示す。一般的 な $\mathrm{PBT}$ 系材料は, 印加電圧 $350 \mathrm{~V}$ ではわずかに表面の黒 化が観察される程度であるが（図 8(a))，600 V では表面 が著しく炭化しトラッキングを生じ, 表層が破壊されてい ることがわかる (図 8(b))。一方, PBT/PLA 系の開発材 料は, 印加電圧 $600 \mathrm{~V}$ でもトラッキングを生じず, 印加電 圧 $350 \mathrm{~V}$ の比較の PBT 系材料と同等な状態として観察さ れる (図 8(c)). 以上の結果から, 開発材料は $600 \mathrm{~V}$ を超 える Comparative Tracking Index (CTI) (UL CTI 試験で, 高電圧部品用のランク 0 相当）を有していることが確認さ れた。この結果は, 芳香環を有さないPLA 独自の構造が, 樹脂組成物の炭化比率の低減に寄与し, 組成物表面の炭化 物形成とそれによる炭化促進を抑制しているためと推定さ れる．本特性もまた，PLAを用いることで発現される新 たなメリットであり, 電気・電子分野への応用に繋がるも 


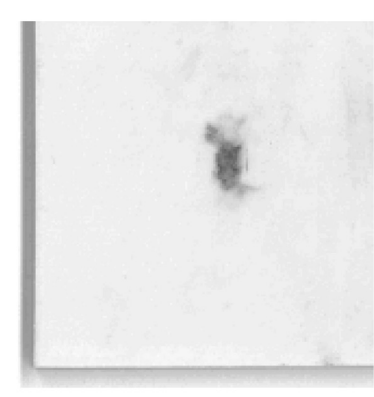

(a) $\mathrm{PBT} / \mathrm{GF}$

(350V)

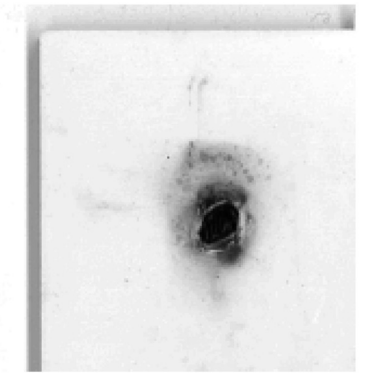

(b) $\mathrm{PBT} / \mathrm{GF}$

(600V)
(c)PBT/PLA/GF開発材料

(600V)

図 8 耐トラッキング性試験後の試験片の外観

のと考えられる。

e. 耐加水分解性

$60^{\circ} \mathrm{C} \cdot 85 \% \mathrm{RH}$ 曝露処理を所定時間行なった後の引張強 さを測定し，未処理の引張強さに対する保持率を求めた. 結果を図 9 に示す. 改良前の PBT/PLA 系材料 (従来材 2) では，処理時間の短い領域でも保持率の低下が顕著である のに対して，PBT/PLA 系の開発材料では，一定処理時間 の領域までは一般的な PBT 系材料と同レベルの傾向を示 している. PLA は易加水分解性 ${ }^{10}$ を有することから，そ の対応が従来求められており, これに対して, 本開発材料 はPBTベースで一定の機械的強度の保持を付与した例で あると言える。

\section{4. 結言}

PLA は, 成形性, 耐熱性, 耐衝撃性, 耐久性などに劣 る樹脂と言われ，単体ベースでの改良が広く進められてい る. 一方で，本開発材料で示したように，成形性，機械的 特性に優れる GF 充填 PBT をべースに複合的な改質をし， 樹脂組成物とすることで, PLA の欠点である前記物性を トータルで改善することが可能であり, PLAの使用範囲 を広げることで，環境・資源への貢献が期待される。また， PLA を用いることで, 樹脂組成物に低そり変形性, 耐卜 ラッキング性を付与しており，PLAの改質材としてのメ リットを提供することも可能となる. 以上から, 今回開発 の材料は，バイオ樹脂である PLAを用いた PBT 系の新 規エンプラ材料として有効であると考えられる.

PLAの成形性については，従来，結晶化時間などで評 価されるケースが多かったが，成形時の形状因子などの影 響もあり，実用面での対応付けが不十分であった。これに 対して, 今回用いた成形性評価方法は, PLA 系材料への 適用に有効であり，本手法により成形性を定量的に把握す ることが可能となる。

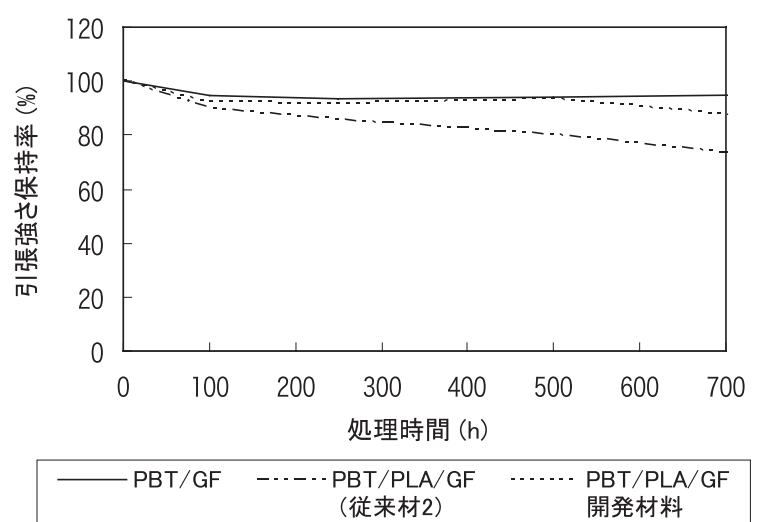

図 $960^{\circ} \mathrm{C} \cdot 85 \% \mathrm{RH}$ 曝露処理後の引張強さの保持率変化

\section{参 考 文 献}

1) IPCC Fourth Assessment Report (AR 4), Climate Change 2007 : Synthesis Report (2007)

2 ）猪俣勲：繊維学会誌（繊維と工業)，67，346(2011)

3 ）川口邦明, 水口一浩, 渡邊美紀, 宇佐美孝司, 鈴木克 利：成形加工'11，149(2011)

4 ）五島一也, 深津博樹, 大須賀晴信, 小林博行：成形加 工'00，201(2000)

5 ）深津博樹, 高嶋正人, 五島一也, 小林博行 : 成形加工 '00, 203(2000)

6 ) バイオプラスチック材料のすべて（日本バイオプラス チック協会編)，日刊工業新聞社，85(2008)

7 ) 武川直祐, 早田祐介, 野寺明夫：第 16 回ポリマー材 料フォーラム予稿集，168(2007)

8 ）廣本恭之：プラスチックスエージ, Dec. 2010, 74 (2010)

9 ）亀尾幸司：高分子，60，519(2011)

10）辻秀人：ポリ乳酸植物由来プラスチックの基礎と応用, 米田出版, 75 (2008) 